Agriculture. The chapter on leather finishing by R. Shaw, drawing on his experience with the Rohm and Haas Co., is out of place in the present volume. It is also more discursive and qualitative than is required in a monograph.

It is unfortunate that analytical and physical testing methods for leather are still not co-ordinated by a single body. The commissions of the International Union of Leather Chemists Societies have been particularly successful in securing agreed physical test methods which many countries are adopting and have also made progress with chemical analytical methods. The American Leather Chemists Association (A.L.C.A.) has, however, continued to develop methods independently. This division is reflected in the various chapters of this book, with often a disproportionate emphasis on the A.L.C.A. methods.

The discussion of analytical methods, particularly when their basis is largely ompirical as is often the case with leather and its raw materials, does not make easy reading. Nor is the quotation in full of an A.L.C.A. mothod justified. A fuller discussion of the accuracy needed in the various determinations would have been valuable, compared with that provided by the methods given.

The chapters on physical testing have greater general interest, especially that by Mieth Maeser on dynamic and non-destructive tosting, which refers especially to shoe leathers and their performance.

The American Chemical Society's leather monograph first appeared under the authorship of J. A. Wilson, who presented a coherent and forceful point of view, in some instances outlining approaches only recently being taken up again. The change to the present multi-volume form, with a wide array of authors, has necessarily resulted in the loss of unified consideration. The chapters have varied in merit and value more than is usual in a book of this character, but this reflects the limited number of persons making significant contributions to leather science and technology. Despite the faults, to which reference has been made, access to the final volume and to the whole work will be a necessity for all seriously concerned with leather, although their use of them will require that they be discriminating.

A. G. WARD

\section{APPLIED ECOLOGY}

\section{Ecology and the Industrial Society}

Edited by Gordon. T. Goodman, R. W. Edwards and Dr. J. M. Lambert. (A Symposium of The British Ecological Society, Swansea, 13-16 April 1964.) Pp. viii +395 . (Oxford: Blackwell Scientific Publications, 1965.) $70 s$. net.

MONG the outstanding questions raised by this, the A British Ecological Society's fifth symposium volume, is the future of ecology as a source of practical guidance for the management of our man-dominated onvironment. Although the Society has, by the publication last year of the Journal of Applied Ecology, asserted that ecology has such a role, the sixteen articles in this volume are not unanimous on this point. In his oponing address Prof. Clapham advocates the direction of university research towards increasing biological productivity and providing a scientific basis for conservation policy, a view that is supported by Britain's full backing of the International Biological Programme. This view is also implicit in suggestions by several authors that reclamation policies are far too empirical and lack a basis in theory. The opposite view is ably put, however, by Hynes, who claims that, in the field of water pollution, the scientific knowledge already exists and that current probloms are nearly all in the fields of administration and politics. That such differences are not solely duo to differing progress in differont fields is indicatod by Hawkes's views that, in the closely related field of sewage treatment, many fundamental ecological problems remain.
In fact a striking characteristic of many papers in this collection is the revelation of interesting fundamental problems at the root of purely practical investigations. A few examples aro: (a) Bradshaw's demonstration that extreme conditions in contaminated environments can facilitate the study of high-spoed population evolution and that conspecific plant populations have rigid spatial boundaries in contaminated ground; $(b)$ Hawkes's views on the effect of temperature on turnover and biomass of sewage decomposers and the stimulation of bacterial activity by grazing animals; (c) Temploton's stress on the need for food chain studies of marine pollution by atornic wastes (consumption of Porphyra (laverbread) in Swansea limits waste disposal from the Windscale plant in Cumberland), and his demonstration that radionucleides in the sea sink or float according to their role in phytoplankton physiology.

There are, however, many points of more immediate practical importance: Hynes contends that much routine toxicity testing is a waste of money because the laboratory tests used are not related to survival in Nature; Moore concludes that we have now reached the time when fish for human consumption should be monitored for organic chlorine residues; Hawkes believes that sewage treatment in many places to-day is inferior to the best practices of tho Assyrians and the Babylonians, and that disoasos such as bovine cysticercosis are on the increase as a result; Gilbert's demonstration that the species range of lichens provides a practical method for detecting air pollution.

This is a well-edited book, well provided with indexes and well illustrated; the only error which seems important enough to mention is the maximal figure (p. 249) of " 900,000 invertebrate animals per $\mathrm{m}^{2}$ of soil" ; this must surely apply to arthropods only, for nematodes occur in their tens of millions and Protozoa in far greater numbers. Inevitably the volume contains highly specialized papers in which little attempt is made to relate the material to the rest of the symposium or explain its significance, although these are far fewer than in many such volumes. The custom of publishing all papers read at meetings (and presumably chosen by the editors in tho first place) is well establishod, but it costs editors' time and readers' money; perhaps future organizers might reserve the right at the outset to publish only a proportion of the more successful papers.

A. Macfadyen

\section{'STRASBURGER' REVISED}

\section{Strasburger's Textbook of Botany}

Rewritten by R. Harder, W. Schumacher, F. Firbas and D. Von Denffer. New English Edition from the Twentyeighth German edition. Translated by Petor Bell and David Coombe. Pp. xvi +846 . (London: Longmans, Green and Co., Ltd., 1965.) 84s.

THE publication of a now English edition of Stras1 burger's Textbook of Botany is an important event for many English-speaking students of the subject. Most pre-war studerits of botany were well acquainted with the previous English edition, published in 1930, but in the absence of more recent translations of the later German editions, it is scarcely surprising that 'Strasburger' is not so well known to moderm studonts. Eleven German editions have appeared since the last English edition and the present translation is from the twenty-eighth German odition, published in 1962.

As in previous editions, four well-known authors deal with the principal aspects of botany: D. Von Denffer with morphology, W. Schumacher with physiology, R. Harder with lower plants, and F. Firbas with seed plants and plant geography. The whole is a remarkably comprehersive account which provides a valuable introduction to almost all aspects of botanical science.

Some botanists have questioned the value of extensive compilations of this kind and prefer shorter accounts of 